\title{
BAHASA, TUBUH, DAN PARADIGMA PATRIARKI DALAM HUMOR KONTEMPORER INDONESIA
}

\author{
Ferry Fauzi Hermawan, Dana Waskita, \& Tri Sulistyaningtyas \\ Kelompok Keahlian Ilmu Kemanusiaan FSRD, Institut Teknologi Bandung \\ E-mail: fauziferry@gmail.com \\ DOI: http://dx.doi.org/10.17509/bs_jpbsp.v17i1.6955
}

\begin{abstract}
Abstrak
Penelitian ini bertujuan untuk menganalisis konstruksi perempuan dalam humor Indonesia yang muncul melalui aplikasi percakapan whatsapp. Analisis ini dilandasi pemikiran Crawford (2003) dan Sen (2012) tentang hubungan gender, linguistik, dan humor. Dalam tulisan ini yang dikaji adalah penggunaan makna indeksial dan polisemi pada cerita humor dalam mengonstruksikan perempuan. Setelah dilakukan analisis, humor yang berkembang dalam media aplikasi percakapan whatsapp cenderung bersifat seksis dengan melanggengkan nilai-nilai patriarkis seperti menggambarkan perempuan sebagai sosok yang pasif dan pasrah. Ditinjau dari segi struktur sebagian besar humor menggunakan teknik ketidaksejajaran dalam upaya menimbulkan nilai humor di benak pembaca. Sebagian besar tokoh perempuan yang muncul berada dalam ruang privat atau domestik. Selain itu, data menunjukkan bahwa sebagian besar humor menggunakan bahasa polisemi figuratif, khususnya dalam menggambarkan aktivitas seksual. Dalam hal ini perempuan selalu diasosiasikan dengan bendabenda mati, seperti untuk menggambarkan aktivitas seksual maupun alat kelamin yang dimiliki oleh perempuan. Makna indeksial dari bahasa yang dipergunakan selalu didasarkan pada paradigma dan kepentingan laki-laki yang sejalan dengan nilai-nilai patriarkis. Hal ini pada akhirnya menimbulkan kekerasan simbolis pada perempuan.
\end{abstract}

Kata kunci: humor, polisemi, kekerasan simbolik, perempuan

\section{LANGUAGE, BODY, AND PATRIARCHY PARADIGM IN INDONESIAN CONTEMPORARY HUMOUR}

\begin{abstract}
This study aims to analyze the construction of women in Indonesia humors that appear through the application of whatsapp conversation. This analysis is based on the opinion of Crawford (2003) and Sen (2012) about gender relations, linguistics, and humors. The focus of the study is the use of indeksial meaning and polysemy in constructing a humorous story in women. After the analysis, it was found that humors developing in the application media of whatsapp conversation tended to perpetuate sexist patriarchal values such as portraying women as a highly compliant and passive. In terms of the structure, most of the humors used several techniques of misalignment to cause the value of humor in the reader's mind. Most of the female figures appeared to be in the private or domestic space. In addition, the data show that most of the humors used figurative polysemy, especially in describing sexual activities. In this case, the women were always associated with inanimate objects, such as in describing sexual activities or woman genitals. The indeksial meanings of the language used were always based on the paradigm and the interests of men that are in line with patriarchal values. This eventually led to symbolic violence on women.
\end{abstract}

Keywords: humors, polysemy, symbolic violence, women 


\section{PENDAHULUAN}

Humor merupakan salah satu bentuk kebudayaan yang banyak berkembang di berbagai bangsa. Humor tidak hanya berperan dalam memberikan aspek hiburan semata bagi komunitas pendukungnya, tetapi dapat menjadi sarana ekspresi, kritik, bahkan katarsis perasaan yang dialami oleh para anggota masyarakat.Meyer (2000) mengibaratkan humor sebagai sebuah ventilasi yang melalui hal itu kita dapat melihat apa yang sebenarnya dirasakan, ditakutkan, dan dikonstruksikan dalam sebuah komunitas. Oleh karena itu, humor dapat dijadikan sebagai sebuah jalan untuk memahami perkembangan peradaban sebuah masyarakat.

Dalam laporan yang diturunkan oleh situs theguardian.com, 21 November 2016, disebutkan bahwa kehidupan masyarakat Indonesia tidak bisa dilepaskan dari unsur humor. Bagi masyarakat Indonesia, segala persoalan kehidupan yang dialami selalu dilihat dari segi humor, baik ekonomi, sosial, politik, maupun agama. Salah satu ciri dominan pemanfaatan unsur humor dalam masyarakat Indonesia adalah dalam hal penyampaian kritik.

Humor, sebagai salah satu medium seni dan komunikasi, memiliki peran yang cukup besar dalam menyampaikan kritik di Indonesia. Hal tersebut telah aktif dilakukan misalnya pada masa Orde Baru. Di tengah tindakan represif Orde Baru, humor menjadi alat katarsis warga dalam mengkritik dan menghadapi sikappemerintah yang dipandang merugikan masyarakat. Pemanfaatan humor sebagai media kritik berlanjut hingga pada era reformasi sebagaimana dapat dilihat pada penelitian Jatnika, dkk. (2015) yang menganalisis kemunculan meme pada masa pemilihan Presiden Indonesia pada tahun 2014.

Di Indonesia, sebagaimana dicatat oleh Rahmanadji (2007) humor berkembang melalui beberapa cara. Pertama, humor berkembang lewat berbagai bentuk kesenian rakyat dan grup lawak. Grup Srimulat merupakan salah satu contoh kelompok kesenian yang konsisten membawakan unsur humor sehingga populer di kalangan masyarakat. Kedua, humor yang berkembang mengikuti keberadaan media massa, seperti koran, radio, televisi, dan surat kabar. Simbiosis keberadaan humor dan media massa ini dimulai pada periode tahun1960an hingga masa reformasi di Indonesia. Salah satu media humor yang cukup dikenal oleh masyarakat kala itu adalah majalah STOP.

Jika sebelumnya humor di Indonesia berkembang melalui medium media cetak, kesenian rakyat, ataupun grup lawak, berkat kemajuan teknologi sirkulasi humor makin berkembang dengan pesat. Salah satu hal yang tidak dapat dikesampingkan adalah keberadaan media sosial, khususnya aplikasi percakapan (chat), yang saat ini menjadi wadah utama penyebaran humor di Indonesia. Kemunculan media sosial telah menyebabkan siapa saja dapat memproduksi atau bahkan mereproduksi humor untuk disebarkan ke khalayak. Jika dulu humor hanya disajikan oleh otoritas tertentu, misalnya redaktur majalah humor ataupun grup lawak tertentu, maka saat ini orang dapat menciptakan, mereproduksi, dan menyebarkan humor masing-masing dengan sekali klik. Saat ini, setiap orang dapat menjadi produsen dan konsumen sekaligus.

Sebagai masyarakat yang masih didominasi nilai-nilai patriarki, salah satu humor yang banyak berkembang dalam media sosial di Indonesia adalah humor yang berkaitan dengan perempuan. Dalam perkembangan wacana humor tradisional perempuan memperoleh posisi yang inferior. Perempuan menjadi objek yang pasif baik jika dilihat dalam segi penceritaan maupun dilihat dari segi penyebaran cerita humor yang banyak dikuasai oleh otoritas lakilaki. Perempuan yang bergelut dalam dunia humor, misalnya memperbincangkan humor yang berkaitan dengan humor seksual dapat dianggap melanggar tabu. 
Namun, perkembangan media sosial yang demikian masif menyebabkan humor yang beredar di media sosial dapat disebarkan oleh siapapun tanpa memperhatikan jenis kelamin, gender, agama, ataupun tingkat pendidikan tertentu. Sebagaimana dipaparkan oleh Crawford(2003) humor dapat menjadi jalan untuk membicarakan topik-topik tabu yang selama ini tidak mungkin terungkapkan secara langsung seperti persoalan ras, seksualitas, politik, agama, maupun yang lainnya. Melalui humor hal tersebut dapat masuk ke dalam wacana masyarakat tanpa harus merasa takut untuk mendapatkan hukuman atau sangsi. Tulisan ini hendak melakukan analisis terhadap beberapa cerita humor yang berkembang di media sosial, khususnya aplikasi percakapan whatsapp, untuk melihat bagaimana perempuan dikonstruksikan melalui humor. Crawford(2003) mengungkapkan bahwa humor memiliki banyak peran dalam pembentukan gender dan seksualitas di masyarakat.De Koning, E. D. dan Weiss(2002) mengungkapkan analisis humor dapat menunjukkan bagaimana laki-laki menanamkan manifestasi dominasi dan kekuasaan dalam kerangka sosial masyarakat terhadap perempuan, khususnya dalam masalah gender dan seksualitas. Tujuan dari analisis yang dilakukan adalah dapat diketahui bentuk-bentuk konstruksi seperti apakah yang terekam, diabadikan, atau bahkan digugat mengenai perempuan yang muncul dalam humor kontemporer di Indonesia, khususnya yang berkembang dalam media aplikasi whatsapp.

Saat ini keberadaan bahasa tidak hanya dipandang sebagai alat komunikasi semata yang bebas nilai. Bahasa, sebagaimana telah ditunjukkan oleh berbagai kajian dan teoritikus, merupakan sebuah arena tempat berbagai kepentingan, ideologi, konstruksi, dan aspirasi sosial berlangsung. Bahasa tidak lagi dipandang sebagai rangkaian huruf yang memiliki satu makna saja. Dalam kaitannya dengan gender dan seksualitas, bahasa merupakan alat utama dalam pembentukan dan penguatan posisi gender dan seksualitas dalam masyarakat. Bahasa merupakan sebuah alat performansi sekaligus penanda identitas gender para anggota sebuah komunitas Cameron (2005). Dalam pemikiran Butler (1990) gender merupakan apa yang ditampilkan bukan sesuatu hal yang terberi (given). Rangkaian performansi dan pengulangan aksi ini membutuhkan penanda-penanda khusus dalam memenuhi peran gender feminin dan maskulin dalam masyarakat. Menurut Cameron (2005) salah satu penanda utama tersebut adalah melalui bahasa. Bahasa yang digunakan oleh setiap penutur dalam berkomunikasi dapat menunjukkan bagaimana sebuah identitas sosial, kultural, dan gender dikonstruksikan.

Dalam penelitian Kiesling (2007) setiap unsur linguistik yang dimiliki oleh sebuah masyarakat memiliki makna indeksikal yang mengacu pada pengonstruksian gender dalam masyarakat. Misalnya pada makna indeksial lingustik yang menganggap perempuan dipandang harus memiliki suara yang lembut dibandingkan laki-laki yang memiliki suara lebih berat. Hal ini berakibat pada pengonstruksian posisi perempuan dan laki-laki di tengah masyarakat. Perempuan dipandang cocok untuk berada dalam ranah privat karena dipandang ranah privat merupakan wilayah yang lembut dan tidak agresif dibandingkan laki-laki yang dipandang cocok berada dalam ranah publik.

Bagi Crawford(2003) humor sebagai sebuah bentuk wacana yang berkembang dan dikembangkan dalam masyarakat merupakan salah satu wadah yang didalamnya terkandung sistem makna yang melalui hal itu dapat dilihat bagaimana gender diperformansi dan diproduksi secara terus menerus. Salah satu hal yang dapat dijadikan analisis adalah bagaimana bahasa dioperasikan dan dikonstruksikan dalam humor tersebut dalam membentuk pemahaman gender dan seksualitas. 
Oleh karena itu, pada akhirnya dan stereotip yang menghegemoni. dikenal dengan apa yang disebut Kedua, humor feminis yang menunjukkan sebagai humor seksis atau humor yang manifestasi kebebasan dan kekuatan dalam mendiskreditkan gender tertentu. Ada empat mengekspresikan pikiran dan perspektif komponen yang dapat dilihat apakah sebuah humor dapat dikategorikan ke dalam humor seksis atau tidak, khususnya yang berkaitan dengan perempuan (Shifman \& Lemish, 2010). Pertama, humor yang berusaha mengejek perempuan, menekankan pada sisi inferioritas perempuan terhadap laki-laki. Kedua, humor yang menargetkan perempuan baik secara langsung maupun tidak langsung, tetapi pada banyak segi cenderung impilisit (misalnya menggunakan berbagai stereotip yang merendahkan bagi perempuan). Ketiga, humor yang menyebarkan stereotip tradisional yang menggambarkan perempuan sebagai sosok yang bodoh, bergantung, tak berlogika, dan hanya sebagai objek seksual semata. Terakhir, keempat, humor yang seksis tidak hanya menekankan bahwa perempuan dan laki-laki memiliki ciri yang berbeda, tetapi lebih jauh melanggengkan posisi hierarki bahwa perempuan lebih inferior dibandingkan laki-laki.

Namun demikian perkembangan internet yang semakin massif menyebabkan humor seksis mendapatkan tantangan dengan berkembangnya humor yang justru melawan sifat seksis tersebut. Salah satu hal yang muncul adalah apa yang disebut Crawford (2003) sebagai humor feminis yaitu humor yang mendekonstruksi pandangan tradisional gender dengan melakukan resistensi konstruksi dominan mengenai femininitas. Mengutip Shifman \& Lemish(2010) internet memiliki karakteristik yang khas, yaitu dibutuhkannya partisipasi aktif dari para pengguna untuk memproduksi konten, hal ini menyebabkan munculnya kesempatan berbicara kepada khalayak mereka yang selama ini termarginalkan secara sosial, termasuk perempuan. Menurut keduanya terdapat empat ciri dari humor feminis. Pertama, humor feminis yang menunjukkan perlawanan terhadap ketidakadilan gender dalam melihat realitas sosial; dalam beberapa segi laki-laki menjadi target utama. Ketiga humor feminis secara eksplisit fokus pada gender. Keempat, biasanya humor feminis membutuhkan ranah dan medium yang berbeda dengan media konvensional untuk mengekspresikan humor-humor tersebut. Salah satu media yang strategis untuk menyebarkan humor-humor feminis ini adalah media sosial, sebab karakteristik media sosial yang tidak menghiraukan siapa yang melakukan produksi dan keanonimitasan para pembuatnya dapat dijaga.

\section{METODE}

Dalam penelitian ini, kami mengumpulkan secara random humor-humor yang muncul di whatsapp. Proses pengumpulan ini kami lakukan dari 10 Januari 2016-15 Desember 2016.Sebagai informasi kami mengikuti 13 grup dalam aplikasi whatsapp. Latar belakang orang-orang dalam grup tersebut beragam baik dilihat dari segi ekonomi, pendidikan, agama, maupun budaya. Selama periode pengumpulan data, humor yang muncul tidak semua memiliki kaitan dengan gender maupun seksualitas. Beberapa humor yang muncul memiliki tema yang beragam seperti politik, pendidikan, dunia selebritas, maupun humor yang mengkritisi kejadian aktual di masyarakat. Beberapa humor muncul berulang-ulang dan disebarkan dari satu grup ke grup yang lain. Oleh karena itu, kami memutuskan mengambil beberapa sampel secara random. Namun demikian, pengambilan sampel ini didasarkan pada kepopuleran atau tingkat frekuensi yang muncul dari satu grup ke grup lain. Misalnya, humor yang berjudul Just Joke.... *CURHAT PARA IsTRI .. $\square *$ yang hampir seluruh grup yang diikuti oleh kami memunculkan humor ini. Sebagaimana dikatakan olehShifman \& Lemish(2010) kita harus bersikap 
kritis akan kepopuleran sebuah humor. Hal ini disebabkan humor merupakan cerminan sosial yang darinya kita dapat mengasumsikan bahwa teks humor tersebut dapat memberikan kita akses untuk mengetahui nilai yang terdapat dalam sebuah komunitas, seperti persepsi mengenai gender. Selain kepopuleran, kami memilih humor yang dijadikan data dengan melihat ada atau tidaknya tokoh perempuan dalam humor tersebut. Walaupun sebuah humor memiliki kepopuleran yang tinggi namun tidak memiliki tokoh perempuan di dalamnya maka kami tidak memasukkan humor tersebut ke dalam data yang hendak kami analisis.

Analisis yang dilakukan oleh kami bersandar pada apa yang dipaparkan olehCrawford(2003)dan Sen(2012). Senmengungkapkan bahwa terdapat dua cara yang dapat dilakukan dalam menganalisis humor yaitu menganalisis tipe ujaran dan tulisan. Dalam tulisan ini yang akan dilakukan adalah mengkaji tulisan yang terdapat dalam humor yang berkembang dalam aplikasi percakapan whatsapp untuk melihat bagaimana gender diperformansikan, direproduksi, atau bahkan didekonstruksikan. Analisis yang kami lakukan terdiri atas dua bagian. Pertama, analisis mengenai struktur cerita humor. Pada bagian ini akan dibahas mengenai teknik dan struktur yang ada dalam data. Pada bagian kedua akan dilakukan analisis bagaimana bahasa dipergunakan untuk memperformansikan, mengonstruksikan, atau mendekonstruksikan sosok perempuan.
Pada bagian ini kami mengkhususkan analisis pada penggunaan polisemi untuk mengetahui makna indeksial linguistik yang dipergunakan dalam cerita humor. Dari data yang dikumpulkan kami akan melakukan analisis terhadap delapan humor yang kami anggap populer dalam aplikasi whatsapp yaitu cerita humor yang berjudul Just Joke.... ${ }^{*} \mathrm{CURH} A T$ PARA IsTRI.. $\square$ *, Pak Cerita Haji mengawinkan ke-4 anaknya, dan *Tulale vs Telpon Umum*.

\section{HASIL DAN PEMBAHASAN}

Pada bagian ini akan dilakukan analisis mengenai teknik dan struktur yang terdapat cerita humor Indonesia. Pada bagian ini akan dianalisis teknik ketidaksejajaran dan penggunaan polisemi yang dipergunakan dalam cerita humor. Kedua, analisis mengenai unsur tanda linguistik yang dipergunakan untuk mengonstruksikan tokoh perempuan yang terdapat dalam cerita humor.

Secara garis besar, humor yang dijadikan sebagai sampel data banyak menggunakan teknik ketidaksejajaran (incongruity). Veale (2004) mengemukakan bahwa teknik inkongruitas adalah suatu kondisi ketidakcocokan antara apa yang individu harapkan akan sesuatu dengan kenyataan yang terjadi. Rahmanadji (2007) memaparkan bahwa dalam teoriketaksesuaian perasaan lucu timbul karena kita dihadapkan pada situasi yang sama sekali tak terduga atau tidak pada tempatnya secara mendadak, sebagai perubahan atas situasi yang sangat diharapkan. Rahmanadji mencontohkan dengan humor yang seseorang yang sedang memancing (Gambar 1).

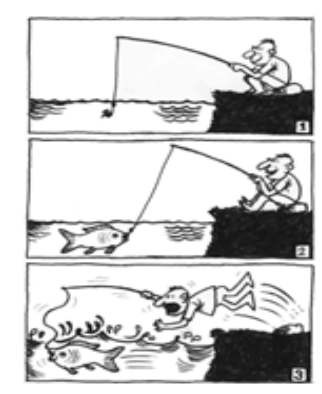

Gambar 1. Contoh Teori Ketidaksejajaran dalam Humor (Sumber: Rahmanadji, 2007) 
Dari gambar di atas kita dapat melihat pada gambar pertama terdapat seseorang yang sedang menungguumpannya dilahap ikan. Dari gambar kedua kita dapat melihat bahwa umpan tersebut dimakan oleh ikan. Namun, pada gambar ketiga kita melihat bahwa justru secara tiba-tiba orang tersebut tercebur ke sungai karena justru ikan tersebut menyeret sang pemancing. Ketidaksejajaran (incongruity) hadir dalam adegan tersebut. Dalam adegan yang terdapat pada gambar 1 dan 2 dibangun sebuah mental pada benak pembaca mengenai kegiatan memancing. Namun, pada gambar ketiga mental tersebut dibenturkan dengan peristiwa yang terseretnya pemancing akibat ikan yang dipancingnya. Ketidaksejajaran inilah yang menimbulkan rasa humor di benak pembaca.

Dari data yang dikumpulkan, hampir semua humor yang muncul menggunakan teknik ketidaksejajaran. Elemen ketidaksejajaran yang dihadirkan berfungsi untuk menghadirkan efek kejutan kepada pembaca sehingga pada akhirnya pembaca diharapkan untuk tertawa ketika membaca humor tersebut.Hal ini misalnya dapat dilihat pada cerita humor yang berjudul Just Joke....*CURHAT PARA IsTRI .. ${ }^{*}$ berikut ini.

\section{Just Joke....*CURHAT PARA IsTRI .. $\square *$}

Beberapa istri yg suaminya *TENTARA , POLISI , SATPOL PP ,* dan

*SATPAM* sedang saling curhat soal perilaku suami mereka

*Wati, yg istri Tentara*, memprotes suaminya saat di kamar spt ini: *'Mas, kenapa sih cepet banget? ....!!*”'Sang suami dgn tegas dan lantang menjawab: "Aku ini *Tentara* dik, jadi sekali mengeluarkan senjata harus langsung tembak. Apalagi dlm *keadaan sdh terjepit ....* Ingatlah filosofi tentara *"Kill or to be Killed"*, jadi tdk boleh keduluan!" .

*keluhan Novi , istri Polisi ,* kepada suami nya *"Kenapa sih lama banget keluarnya, mas .* Dengkulku sampai teklok mau copot, capeeeek deeeh ....."Sang suami dgn sigap menjawab: *'Aku ini Polisi , *dik .... Walau senjata sdh diacungkan, tapi menembak itu *tindakan paling akhir kalau tidak ada alternatif lain,... *jangan sampai melanggar HAM....* Ingatlah dik akan filosofi Polisi *'Fight Crime, Love Humanity, Help delinquent”.* Jadi tdk boleh nembak sembarangan ....! Sabar yaa, dik...

*Bu Dini, yg suaminya satpol PP ,* menanggapi: "Itu sih masih bagus, bu. Lha saya *tiap malem cuma di obrak abrik tp tdk di tembak-tembak* .....

*Bu Anjari, yang suaminya Satpam* sambil manyun berkata:"Ah ibu-ibu ini jgn suka mengeluh. itu sih masih belum seberapa. Lha *saya ini tiap malem cuman dibuka tutup doang*... Emangnya *saya ... portal !!”

Ketika membaca humor di atas pembaca diajak untuk mendengarkan percakapan yang terjadi antara Wati (istri Tentara), Novi (istri polisi), Bu Dini (istri Satpol PP), dan Bu Anjari (istri satpam). Humor ini dibangun oleh keluh kesah ketidakpuasan Wati, Novi, dan Bu Dini mengenai hubungan seksual mereka dengan suaminya. Hubungan seksual yang terjadi di antara ketiganya digambarkan sesuai dengan moto korps suami masing-masing. Inilah elemen pembangun dalam humor di atas. Akan tetapi, pada akhir cerita hal ini justru ditubrukan dengan ungkapan yang diberikan oleh Bu Anjari yang suaminya berprofesi sebagai satpam. Jika ketiga perempuan sebelumnya berbicara mengenai aktivitas seksual mereka dengan suaminya yang dibayangkan sesuai dengan korps masingmasing, maka hal menarik justru terjadi pada diri $\mathrm{Bu}$ Anjari. Walaupun aktivitas seksual yang terjadi disamakan dengan pekerjaan 
suami sebagaimana ketiga perempuan lain, $\mathrm{Bu}$ Anjari justru tidak mendapatkan hubungan seksual seperti yang lain. Inilah elemen ketidaksejajaran yang muncul dalam Just Joke....*CURHAT PARA IsTRI .. $\square *$ yang diharapkan menimbulkan tawa pada pembaca karena menjungkirbalikkan konstruksi cerita yang sebelumnya telah dibangun. Selain kisah humor di atas, salah satu cerita humor yang mempergunakan teknik ketidaksejajaran adalah kisah yang berjudul Warning berikut ini.

\section{WARNING}

Kawan2, bagi yang hendak lewat jalur demo hari ini, mohon berhati-hati.

Tiga anak Dr. Azhari (teroris yg tewas di Malang thn 2005) akan berada ditengah kerumunan massa. Mereka membawa 2 bom besar di dadanya! Mereka adalah:

Ayu Azhari,

Sarah Azhari

Rahma Azhari

Cerita humor di atas dibangun oleh konstruksi mengenai tingkat keamanan pada sebuah demonstrasi yang akan dilaksanakan. Benak pembaca dikonstruksikan dengan keadaan genting karena demo tersebut diyakini disusupi oleh anak dari Dr. Azhari, salah seorang teroris terkenal yang pernah menimbulkan kekacauan di Indonesia. Inilah elemen pembangun dalam cerita humor yang berjudul Warning. Konstruksi cerita ini pada akhirnya diruntuhkan dengan muncul bahwa anak-anak Dr. Azhari yang dicurigai akan membawa bom adalah tiga orang artis yang berasal dari keluarga Azhari. Bom yang pada mulanya memiliki bangun makna sebagai bahan peledak runtuh karena bom yang dimaksudkan dalam cerita ini adalah payudara. Inilah elemen ketidaksejajaran yang diharapkan akan menimbulkan tawa dalam benak pembaca. Berikut ini adalah tabel teknik ketidaksejajaran yang ada dalam data.

Tabel 1. Elemen ketidaksejajaran yang dipergunakan dalam data humor

\begin{tabular}{|c|c|c|}
\hline Judul & Elemen Pembangun Humor & Elemen Ketidaksejajaran \\
\hline $\begin{array}{l}\text { Just } \\
\text { Joke....*CURHAT } \\
\text { PARA IsTRI } \\
\text {...8* }\end{array}$ & $\begin{array}{l}\text { Ketika membaca humor ini pembaca diajak } \\
\text { untuk mendengarkan percakapan yang terjadi } \\
\text { antara Wati (istri Tentara), Novi (1stri polisi), } \\
\text { Bu Dini (istri Satpol PP), dan Bu Anjari (istri } \\
\text { satpam). Humor ini dibangun oleh keluh } \\
\text { kesah ketidakpuasan Wati, Novi, dan Bu Dini } \\
\text { mengenai hubungan seksual mereka dengan } \\
\text { suaminya. Hubungan seksual yang terjadi di } \\
\text { antara ketiganya digambarkan sesuai dengan } \\
\text { moto korps suami masing-masing. }\end{array}$ & $\begin{array}{l}\text { Aktivitas seksual yang dilakukan oleh } \\
\text { Bu Anjari yang ternyata tidak sesuai } \\
\text { dengan ketiga perempuan lain. }\end{array}$ \\
\hline $\begin{array}{l}\text { Pak Haji } \\
\text { Mengawinkan } \\
\text { Anaknya }\end{array}$ & $\begin{array}{l}\text { Benak pembaca dikonstruksikan untuk proses } \\
\text { aktivitas seksual rang dilakukan oleh keempat } \\
\text { anak Pak haji yang menikah untuk pertama } \\
\text { kalinya. Pak haji memerintahkan kepada } \\
\text { keempat anaknya apabila telah melakukan } \\
\text { hubungan seksual semuanya harus } \\
\text { memberitahukan pengalamannya kepada } \\
\text { ayahnya. Ketiga anaknya memiliki pengalaman } \\
\text { yang memuaskan secara seksual ketika } \\
\text { melaporkan pengalamannya masing-masing. } \\
\text { Hanya saja dari keempat anaknya tersebut ada } \\
\text { satu anaknya yang justru tidak memberikan } \\
\text { kabar kepada Pak Haji. Pak Haji gelisah karena } \\
\text { ditakutkan anaknya tersebut tidak dapat } \\
\text { memuaskan suaminya dari segi hubungan } \\
\text { seksual. }\end{array}$ & $\begin{array}{l}\text { Kegelisahan pak Haji yang } \\
\text { menganggap anaknya gagal dalam } \\
\text { berhubungan justru sebaliknya. Anak } \\
\text { perempuannya justru mengalami } \\
\text { hubungan seksual yang luar biasa } \\
\text { karena dilakukan terus menerus } \\
\text { sehingga dirnya tidak sempat } \\
\text { mengabari kepada ayahnya. }\end{array}$ \\
\hline
\end{tabular}




\begin{tabular}{lll}
\hline Warning & $\begin{array}{l}\text { Adanya anak-anak teroris Dr. Azhari yang Anak-anak Dr. Azhari yang dimaksud } \\
\text { disebut membawa bom ketika demo akan bukanlah teroris tetapi artis yang } \\
\text { berlangsung. }\end{array}$ & $\begin{array}{l}\text { berasal dari keluarga Azhari. Bom yang } \\
\text { dimaksud bukanlah alat peledak tetapi } \\
\text { payudara masing-masing artis. }\end{array}$ \\
\hline Tulale VS & $\begin{array}{l}\text { Pertengkaran yang timbul akibat percakapan } \\
\text { Telepon }\end{array}$ & $\begin{array}{l}\text { Munculnya ajakan dari sang istri untuk } \\
\text { istri marah karena sang suami mengatakan mengasosiasikan aktivitas tersebut }\end{array}$ \\
& $\begin{array}{ll}\text { bahwa alat kelamin milik perempuan seperti dengan kegiatan menelepon di tempat } \\
\text { telepon koin umum. }\end{array}$ & umum.
\end{tabular}

Selain banyak menggunakan teknik ketidaksejajaran dari analisis struktur diketahui pula bahwa hampir semua cerita humor yang memiliki tokoh perempuan di dalamnya selalu bercerita dalam konteks keluarga dan ranah domestik. Dalam hal ini tokoh perempuan yang muncul banyak berperan sebagai istri, ibu, dan anak. Hanya satu cerita humor yang tidak secara eksplisit menggambarkan karakter perempuan dalam cerita yaitu pada kisah yang berjudul Warning. Untuk lebih jelasnya dapat dilihat dalam tabel berikut.

Tabel 2. Karakter tokoh perempuan yang terdapat dalam data humor

\begin{tabular}{ll}
\hline Judul & Karakter Tokoh Perempuan \\
\hline Just Joke....*CURHAT PARA IsTRI ..:** & Istri \\
\hline Pak Haji Mengawinkan Anaknva & Istri \\
\hline Tulale Vs Telepon Umum & Istri \\
\hline Warning & Selebritas \\
\hline
\end{tabular}

Dari tabel di atas dapat ditafsirkan bahwa konstruksi sosial masyarakat masih menempatkan perempuan berada dalam ranah domestik. Hal ini misalnya dapat dilihat dari latar atau ruang yang dipergunakan dalam penceritaan. Dari data yang dikumpulkan, cerita humor yang memiliki tokoh perempuan di dalamnya masih berada di sekitar rumah pribadi atau paling jauh rumah tetangga. Dengan latar utama penceritaan adalah ruang-ruang privat seperti kamar tidur.

Hal ini berbeda apabila dibandingkan dengan cerita humor yang memunculkan tokoh laki-laki sebagai sentral utama penceritaan. Latar atau ruang yang dijadikan sebagai pendukung cerita cenderung lebih luas dan berada dalam ranah publik seperti perkantoran, pemerintahan, sekolah, dan lain-lain. Hal ini diperkuat dengan konflik permasalahan yang dimunculkan yang masih berkisar pada persoalan rumah tangga seperti hubungan seksual. Persoalan hubungan seksual menjadi tema yang banyak muncul dalam data yang telah dikumpulkan.

Selain hal di atas, sampel data menunjukkan bahwa sebagian besar cerita humor yang memiliki tokoh perempuan di dalamnya menggunakan bahasa polisemi figuratif.Wijana(2003)mengungkapkan bahwa polisemi figuratif merupakan salah satu unsur penting dalam mendukung munculnya nilai humor dalam sebuah cerita. Hal ini disebabkan sebuah kata dapat membentuk makna yang berbeda-beda tergantung konteks penceritaan. Misalnya, kata burung yang memiliki makna literal sebagai jenis unggas. Namun, dalam cerita humor kata burung sering diasosiasikan sebagai alat kelamin laki-laki. Inilah yang disebut sebagai polisemi figuratif.

Mengacu kepadaSumarsono(2006) yang mengungkapkan bahwa bahasa figuratif bisa dibentuk karena adanyan penyimpangan penerapan makna kepada sesuatu referen yang lain. Penyimpangan ini tidaklah bersifat arbitrer tetapi berdasarkan atas kesamaan 
tertentu, misalnya sifat, bentuk, fungsi, tempat ataupun kombinasi di dalamnya. Dari data yang dikumpulkan polisemi figuratif banyak dipakai untuk mengemukakan hubungan seksual dan gambaran tubuh perempuan.

Di dalam cerita Just Joke....*CURHAT PARA IsTRI .. $\square *$ hubungan seksual dikiaskan sebagaimana pekerjaan para suami yang dimiliki oleh para tokoh istri. Di dalam cerita ini dibayangkan terdapat persamaan sifat antara kekuatan laki-laki dalam aktivitas seksual dan kegiatan pekerjaan yang dilakukan dalam ranah publik. Namun demikian, terdapat perbedaan penggambaran aktivitas seksual antara laki-laki dan perempuan. Tubuh perempuan diasosiasikan sebagai sebuah barang yang dapat dipergunakan oleh laki-laki. Dalam Just Joke....*CURHAT PARA IsTRI .. $\square *$ tubuh perempuan berpolisemi sebagai sebuah portal dan wilayah yang dapat dimasuki sedemikian rupa oleh laki-laki. Bagian tubuh perempuan digambarkan sebagai benda mati yang dapat diperlakukan sedemikian rupa oleh laki-laki. Bahkan dalam cerita Tulale VS Telpon Umum alat kelamin perempuan digambarkan sebagai telepon umum. Kutipannya adalah.

*Tulale vs Telpon Umum*

*_Di ruang TV,_* Si Isteri ngeliat perut suaminya mulai buncit, si isteri nyeletuk

"Pa, Mama tahu kalau di dalam perut Papa pasti ada gajahnya".

*_Suami :_*”Masak di dalam perut ada gajahnya sih ?"

*_Istri :_* "lha itu, belalainya keluar di bawah perut Papa".

*_Suami :_* "kalau di dalam perut Mama pasti ada telpon umum kan".

*_Istri :_* "Gimana bisa ada telpon umumnya di perut".

*_Suami :_*"Lha itu di bawah perut Mama kelihatan lubang koinnya".

*_Si Istri_* ngambek masuk kamar, tak lama kemudian dari kamar terdengar suara

Istri *_"Paaa...gajahnya mau nelpon nggak?"_*

*_ $\square \square \square$ ha...ha....ha.... $\square \square \square \square \square \square \square \square \square$ telpooon aaah...**

Dari kutipan di atas dapat dilihat bahwa terdapat perbedaan penggunaan polisemi antara laki-laki dan perempuan. Kiesling (2007) mengungkapkan bahwa setiap unsur linguistik yang dimiliki oleh sebuah masyarakat memiliki makna indeksikal yang mengacu pada pengonstruksian gender tertentu dalam sebuah masyarakat. Dari data yang diperoleh dapat dilihat bahwa secara umum bagian tubuh laki-laki selalu menggunakan polisemi yang berasosiasi dengan makhluk hidup, sedangkan perempuan selalu menggunakan polisemi yang berasosiasi benda mati. Dari perbedaan penggunaan polisemi yang seperti ini dapat ditafsirkan bahwa masyarakat kita masih menganggap bahwa perempuan sebagai sosok yang pasif dan pasrah, khususnya dalam aktivitas seksual.

Selain hal itu, dari data dapat dilihat bahwa masyarakat masih menganggap hubungan seksual sebagai sesuatu hal yang tabu untuk diungkapkan secara langsung sehingga hampir seluruh kegiatan seksual digambarkan memakai bahasa yang figuratif. Hal ini dapat menyiratkan bahwa masyarakat kita masih memandang hubungan seksual sebagai sesuatu hal yang tabu sehingga harus menggunakan kata-kata kiasan untuk mengungkapkannya. Hal ini misalnya dapat dilihat pada kisah Pak haji mengawinkan keempat anaknya.

Pak Haji mengawinkan ke-4 anaknya, yaitu Anita, Minah, Mirah dan Mumun.

Mereka semua berbulan madu ke Bali.

Sebelum mereka pergi,

pak Haji bilang, 
"Nak, ntar pd kirim kabar ya ke Babe tentang kualitas laki2 kalian masing2. Pake sms aja \& biar gak jorok, pake motto iklan aje yee ?!

Hari ke-1

di bulan madu.

Si Anita kirim SMS ke pak Haji, sms-nya cukup singkat:

"KFC"...

\& Pak haji langsung mencari iklan KFC di gerai KFC terdekat \&terbacalah :

"NIKMATNYA SAMPAI KE TULANG"

Pak Haji pun tersenyum2.

Hari ke-2

bulan madu.

Giliran si Mirah yg kirim SMS \& sms-nya juga cukup singkat :

"STANDARD CHARTERED".

Pak Haji pun langsung mencari iklan Standard di koran dan terbacalah tulisan :

"BESAR, KUAT \& BERSAHABAT".

Pak Haji pun langsung tersenyum lebar.

Hari ke-3

Giliran si Mumun yg kirim SMS, isi-nya juga cukup singkat:

"NESCAFE".

Pak Haji pun langsung mencari iklan NESCAFE di koran dan terbaca motto

Nescafe :

"NIKMATNYA SAMPAI TETES TERAKHIR".

Pak Haji pun kembali tersenyum ceria.

Memasuki hari ke-4,5,6 \& 7 Pak Haji mulai risau karena si Minah tak ada kabarnya. Waduuuh, ada apa gerangan dgn si Minah ya.., jangan2 dia dibikin kecewa sama laki2-nya...??

Akhir-nya pd hari ke-8 barulah masuk SMS dari Minah yg isinya juga cukup singkat:

"AIR ASIA “.

Pak Haji sangat penasaran krn yang dia tahu AIR ASIA itu armada penerbangan terbesar di Asia Tenggara.

Langsung Pak Haji cari koran, terbaca-lah motto AIR ASIA :

"7 KALI SEMINGGU -

3 KALI SEHARI -

5 JAM NON STOP”.

Pak Haji pun bilang dalam hati, pantesan dia gak sempet sms, tiap hari jadwal-nya padat bgt... 
Dari kutipan di atas dapat dilihat bahwa bahasa polisemi yang dipergunakan menyandarkan diri pada pandangan laki-laki. Misalnya penggunaan kata "BESAR, KUAT \& BERSAHABAT", "NIKMATNYA SAMPAI TETES TERAKHIR", "NIKMATNYA SAMPAI KE TULANG", "7 KALI SEMINGGU - 3 KALI SEHARI - 5 JAM NON STOP”, merupakan imajinasi laki-laki dalam berhubungan seksual. Dalam masyarakat yang patriarkis laki-laki selalu dibayangkan sebagai sosok yang agresif dan memiliki kekuatan luar biasa dalam aktivitas seksual.

Selain itu, keberadaan tokoh perempuan selalu ditandai dengan bahasa yang memiliki makna indeksial yang berasosiasi tubuh. Dalam cerita Warning keberadaan perempuan hanya dimaknai melalui tubuhnya yaitu keberadaan payudara yang diasosiasikan sebagai bom.

Sebagaimana kisah Pak Haji Mengawinkan Anaknya kata bom dipilih juga menyandarkan diri pada imajinasi laki-laki mengenai keberadaan dan bentuk payudara yang ideal dalam masyarakat patriarkis yaitu payudara yang berbentuk besar. Hal ini diperkuat dengan pemilihan kata-kata Ayu Azhari, Sarah Azhari, dan Rahma Azhari yang diasosiasikan sebagai sosok artis yang seksi dan memiliki payudara ideal dalam masyarakat.

Dari pemilihan dan penggunaan bahasa yang seperti ini dapat dilihat bahwa terjadi semacam kekerasan simbolik dalam masyarakat. Perempuan dianggap sebagai sosok yang pasrah, benda mati, dan kehadirannya didasarkan kepada konstruksi laki-laki semata. Kekerasan semacam ini oleh korbannya (kaum perempuan) bahkan tidak dilihatatau dirasakan sebagai kekerasan, tetapi sebagai sesuatu yang alamiah dan wajar (Haryatmoko, 2016). Hal ini terbukti bahwa banyak di antara yang mereproduksi cerita-cerita humor tersebut adalah kaum perempuan. Kaum perempuan secara tidak sadar telah ikut serta melanggengkan nilai-nilai patriarkis melalui humor yang berkembang dalam aplikasi whatsapp.

\section{SIMPULAN}

Setelah dilakukan analisis, humor yang berkembang dalam media aplikasi percakapan whatsapp cenderung bersifat seksis dengan melanggengkan nilai-nilai patriarkis seperti menggambarkan perempuan sebagai sosok yang pasif dan pasrah. Ditinjau dari segi struktur sebagian besar humor menggunakan teknik ketidaksejajaran dalam upaya menimbulkan nilai humor di benak pembaca. Sebagian besar tokoh perempuan yang muncul berada dalam ruang privat atau domestik. Selain itu, data menunjukkan bahwa sebagian besar humor menggunakan bahasa polisemi figuratif, khususnya dalam menggambarkan aktivitas seksual. Dalam hal ini perempuan selalu diasosiasikan dengan benda benda mati, seperti untuk menggambarkan aktivitas seksual maupun alat kelamin yang dimiliki oleh perempuan. Makna indeksial dari bahasa yang dipergunakan selalu didasarkan pada paradigma dan kepentingan laki-laki yang sejalan dengan nilai-nilai patriarkis. Hal ini pada akhirnya menimbulkan kekerasan simbolis pada perempuan.

\section{DAFTAR RUJUKAN}

Butler, J. (1990). Gender trouble: feminism and the subversion of identity. New York: Routledge.

Cameron, D. (2005). Language, gender, and sexuality: current issues and new directions. Applied Linguistics, 26(4), 482-502. http://doi.org/10.1093/ applin/ami027

Crawford, M. (2003). Gender and humor in social context, 35, 1413-1430.

De Koning, E. D. \& Weiss, R. L. (2002). The relational humour inventory: Functions of humour in close relationships. American Journal of Family Therapy, 30(1), 1-18. 
40 Jurnal Pendidikan Bahasa dan Sastra, Volume 17, Nomor 1, April 2017, blm. 29-40

Haryatmoko. (2016). Membongkar rezim kepastian: pemikiran kritis poststrukturalis. Yogyakarta: Penerbit Kanisius.

Jatnika, Wawan, A., Sulistianingtyas, T., \& Hermawan, F. . (2015). Politik bahasa meme pemilihan presiden Republik Indonesia 2014. In Linguistic Scientific Meeting International Conference Faculty of Humanities Postgraduate program Padjadjaran University.

Kiesling, S. F. (2007). Men, masculinities, and language. Language and Linguistics Compass Journal Compilation.

Meyer, J. C. (2000). Humour as a doubleedged sword: four functions of humour in communication. Communication Theory, 10, 310-331.

Rahmanadji, D. (2007). Sejarah, teori, jenis, dan fungsi humor. Bahasa dan Seni, 35(Agustus Nomor 2).

Sen, A. (2012). Update humour analysis and qualitative, (63), 1-4.
Shifman, L., \& Lemish, D. (2010). Between feminism and fun ( ny ) mism: Analyzing gender in popular internet Humor, 13, 870-891.

Sumarsono. (2006). Penyusunan kamus istilah linguistik terapan. Jurnal Pendidikan Dan Pengajaran Undiksha, (3), 1015-1031.

Veale, T. (2004). Incongruity in humour: root cause or epiphenomenon? HUMOUR: International Journal of Humour Research, 17(4), 419-428.

Wijana, I. D. P. (2003). Kartun: studi tentang permainan bahasa. Yogyakarta: Penerbit Ombak.

\section{UCAPAN TERIMA KASIH}

Tim peneliti mengucapkan terima kasih kepada Yani Suryani, Jejen Jaelani, dan Linda Handayani yang telah memberikan komentar dan masukan awal pada draft penulisan artikel. 